\title{
Use of dried waste of cassava starch extraction for feeding lactating cows
}

\author{
TATIANE FERNANDES ${ }^{1}$, MAXIMILIANE A. ZAMBOM ${ }^{2}$, \\ DEISE D. CASTAGNARA ${ }^{3}$, LEILIANE C. SOUZA ${ }^{4}$, \\ DAIANE O. DAMASCENO ${ }^{2}$ and EMERSON L. SCHMIDT ${ }^{2}$ \\ ${ }^{1}$ Departamento de Zootecnia, Universidade Federal de Lavras, \\ Câmpus Universitário, s/n, 37200-000 Lavras, MG, Brasil \\ ${ }^{2}$ Centro de Ciências Agrárias, Universidade Estadual do Oeste do Paraná, \\ Rua Pernambuco, 1777, Centro, 85960-000 Marechal Cândido Rondon, PR, Brasil \\ ${ }^{3}$ Departamento de Medicina Veterinária, Universidade Federal do Pampa, \\ BR 472, Km 592, 97500-970 Uruguaiana, RS, Brasil \\ ${ }^{4}$ Centro de Ciências Agrárias, Instituto Federal do Paraná, Avenida Cívica, 475, \\ Centro Cívico, 85935-000 Assis Chateaubriand, PR, Brasil \\ Manuscript received on June 6, 2014; accepted for publication on November 25, 2014
}

\begin{abstract}
The aim of this study was to determine the best level of utilization of dried waste of cassava starch extraction (WCSEd) as a substitute for corn for lactating cows. Four lactating cows were fed diets with increasing levels $(0 \%, 33 \%, 66 \%$ and $100 \%)$ of WCSEd as a substitute for corn. The intake and digestibility of dry matter and nutrients, milk production and composition, blood parameters of glucose and urea and microbial synthesis of the diets were evaluated. There was a reduction in dry matter intake, organic matter, ether extract and total carbohydrate, and increased intake of acid detergent fiber. Nutrient digestibility was not affected while the synthesis of microbial protein increased. These changes resulted in reduced milk production, without altering the efficiency of production or the constituents of milk, with a decreasing effect on daily production of lactose, solids and minerals. Metabolic parameters, glucose and urea nitrogen in plasma, remained within appropriate levels. The dried residue from the extraction of cassava starch can be used as feed for dairy cows to replace up to $100 \%$ of the corn ration. However, its use promotes a reduction in intake of dry matter and nutrients as well as a reduction in the production of milk, with impacts on the profitability of the product.
\end{abstract}

Key words: blood parameters, digestibility, intake, microbial synthesis, production.

\section{INTRODUCTION}

The expansion of milk production in Brazil had led to a search for alternative foods that would minimize production costs and improve the profitability of producers for whom milk is a source of fixed income. Agroindustrial waste has featured

Correspondence to: Tatiane Fernandes

E-mail: tati-_tati@hotmail.com in this search for alternative foods, since feed costs represent most of the operational costs in milk production (Jobim et al. 2007).

Cassava processing waste can be easily obtained in regions near processing plants, due to the large amount of waste produced and the need for its disposal (Reginatto et al. 2011). This waste is a cheap energy substitute for the formulation of 
feed for ruminants, and as it has a similar nutritive value to corn, it is a viable alternative (Ramalho et al. 2006).

Among the waste produced during the processing of cassava, the residue obtained from the extraction of starch by the wet method is of particular interest. The global demand for native and modified starches is projected to grow from 35 million tons to 50 million between 2011 and 2015 (Felipe et al. 2013), boosting production and increasing the amount of waste. The conservation of this residue is hampered by its high levels of humidity $(85 \%)$ (Abrahão et al. 2006b). The drying of this byproduct would enable its proper conservation and transport, but raise the costs of acquisition.

When using alternative foods, it is important to evaluate the influence of the production and quality of products on food intake (Abrahão et al. 2006a). The present study was thus conducted to determine the best usage level of dried waste of cassava starch extraction (WCSEd), as a substitute for corn in lactating cows.

\section{MATERIALS AND METHODS}

The experiment was conducted at the Universidade Estadual do Oeste do Paraná, Campus de Marechal Cândido Rondon-PR. The experimental protocol was approved by the Ethics Committee on the Use of Animals of UNIOESTE (48/13 Protocol).

We used four multiparous Holstein cows (between $4^{\text {th }}$ and $6^{\text {th }}$ lactation) at approximately 100 days of lactation, with an average body weight of $627.5 \pm 31.5 \mathrm{~kg}$ and an average initial production of $24.21 \pm 5.98 \mathrm{~kg}$ of milk a day. The animals were distributed in a Latin square experimental design $(4 \times 4)$ with four experimental periods of 21 days each, comprising 14 days of adaptation to diet and 7 days of data collection (total period of 84 days) and four treatments. The treatments used were: replacement levels of corn $(0,33,66$ and 100) for dried waste of cassava starch extraction (WCSEd).
A chemical assessment of the diets was conducted, including the levels of DM (dry matter), MM (mineral matter), EE (ether extract) and CP (crude protein), according to the methodology described by AOAC (1990); and NDF (neutral detergent fiber) and ADF (acid detergent fiber), according to Van Soest et al. (1991). OM (organic matter) was obtained by the difference between the MM and the total content of DM (Table I).

The experimental diets were formulated in accordance with the NRC (2001), to meet the requirements of the animal category (Table II). Diets comprised of $50 \%$ corn silage as the forage source, and $50 \%$ of concentrated feed. To estimate the TDN (total digestible nutrients), the in vitro digestibility values of OM (IVDOM) were determined using the methodology described by Tilley and Terry (1963), and described by the equation reported by Kunkle and Bates (1998).

The animals were housed in stables, in individual pens with a trough for intake control. Feed was done twice a day, at 6:30 am and 4:30 $\mathrm{pm}$, as $70 \%$ and $30 \%$, respectively, of the total DM offered. Excess feed was supplied daily in order to provide leftovers of $10 \%$ of the total DM offered. At the beginning and end of each experimental period, the animals were weighed immediately after milking and before feeding in the morning.

During the 7 days of the trial period, sampling of the rations provided and the leftovers was carried out, forming a composite sample, per period and per treatment. For determination of the digestibility of DM and nutrients from the $15^{\text {th }}$ to the $20^{\text {th }}$ day of each experimental period, feces were collected directly at the exit of the rectum at the following times: 8:00, 10:00, 12:00 am, 2:00, 4:00 and 6:00 pm every day.

To obtain estimates of fecal excretion, indigestible neutral detergent fiber (iNDF) was used as an internal indicator, as proposed by Waller et al. (1980). iNDF was determined by ruminal incubation of samples of food, leftovers and feces 
TABLE I

Chemical composition of the dried waste of cassava starch extraction (WCSEd), corn, soybean meal and corn silage, used for formulation of diets.

\begin{tabular}{|c|c|c|c|c|}
\hline Composition & WCSEd & Corn & soybean meal & corn silage \\
\hline Dry Matter $\left(\mathrm{g} \mathrm{kg}^{-1}\right)$ & 869.07 & 880.00 & 886.68 & 307.41 \\
\hline Organic Matter $\left(\mathrm{g} \mathrm{kg}^{-1} \mathrm{DM}\right)$ & 985.60 & 985.74 & 934.04 & 956.38 \\
\hline Crude Protein $\left(\mathrm{g} \mathrm{kg}^{-1} \mathrm{DM}\right)^{1}$ & 14.91 & 95.73 & 514.83 & 81.49 \\
\hline $\mathrm{A}\left(\mathrm{g} \mathrm{kg}^{-1} \mathrm{CP}\right)$ & 200.41 & 195.21 & 126.85 & 548.15 \\
\hline $\mathrm{B} 1\left(\mathrm{~g} \mathrm{~kg}^{-1} \mathrm{CP}\right)$ & 70.79 & 36.48 & 43.58 & 75.16 \\
\hline $\mathrm{B} 2\left(\mathrm{~g} \mathrm{~kg}^{-1} \mathrm{CP}\right)$ & 268.23 & 682.86 & 763.32 & 220.03 \\
\hline $\mathrm{B} 3\left(\mathrm{~g} \mathrm{~kg}^{-1} \mathrm{CP}\right)$ & 157.78 & 19.88 & 62.01 & 47.69 \\
\hline $\mathrm{C}\left(\mathrm{g} \mathrm{kg}^{-1} \mathrm{CP}\right)$ & 302.79 & 65.57 & 04.24 & 108.97 \\
\hline Ether Extract ( $\left.\mathrm{g} \mathrm{kg}^{-1} \mathrm{DM}\right)$ & 03.61 & 06.03 & 06.41 & 23.86 \\
\hline $\mathrm{NDF}\left(\mathrm{g} \mathrm{kg}^{-1} \mathrm{DM}\right)^{2}$ & 393.75 & 124.49 & 134.09 & 494.11 \\
\hline $\mathrm{ADF}\left(\mathrm{g} \mathrm{kg}^{-1} \mathrm{DM}\right)^{3}$ & 216.59 & 46.94 & 79.89 & 284.55 \\
\hline $\mathrm{NFC}\left(\mathrm{g} \mathrm{kg}^{-1} \mathrm{DM}\right)^{4}$ & 573.89 & 730.42 & 263.25 & 343.81 \\
\hline $\mathrm{TC}\left(\mathrm{g} \mathrm{kg}^{-1} \mathrm{DM}\right)^{5}$ & 967.64 & 854.91 & 397.34 & 837.92 \\
\hline $\mathrm{A}+\mathrm{B} 1\left(\mathrm{~g} \mathrm{~kg}^{-1} \mathrm{TC}\right)$ & 607.76 & 893.32 & 767.44 & 440.64 \\
\hline $\mathrm{B} 2\left(\mathrm{~g} \mathrm{~kg}^{-1} \mathrm{TC}\right)$ & 313.46 & 89.27 & 180.07 & 351.90 \\
\hline $\mathrm{C}\left(\mathrm{g} \mathrm{kg}^{-1} \mathrm{TC}\right)$ & 80.23 & 17.41 & 52.50 & 207.47 \\
\hline TDN estimated $\left(\mathrm{g} \mathrm{kg}^{-1}\right)^{6}$ & 80.47 & 82.86 & 70.16 & 70.71 \\
\hline
\end{tabular}

${ }^{1} \mathrm{CP}$ : Crude Protein, A: Soluble fraction, B1: Fraction of rapid degradation, B2: Fraction of intermediate degradation, B3: Fraction of slow degradation and $\mathrm{C}$ : Indigestible fraction; ${ }^{2} \mathrm{NDF}$ : Neutral detergent fiber; ${ }^{3} \mathrm{ADF}$ : Acid detergent fiber; ${ }^{4} \mathrm{NFC}$ : Non-Fibrous Carbohydrates; ${ }^{5} \mathrm{TC}$ : Total Carbohydrates, A+B1: Soluble fraction and rapid degradation, B2: Fraction potentially degradable, $\mathrm{C}$ : non-degradable fraction; ${ }^{6} \mathrm{TDN}$ : Totals digestible nutrients (estimated by TDN $=\mathrm{OM}(\%) / 100$ $(26.8+0.595($ IVDOM $(\%))))$.

for 240 h, into F57 filters (ANKON ${ }^{\circledR}$ Technology Corporation), and an analysis of neutral detergent fiber was then performed (Lippke et al. 1986).

Samples of food, leftovers and feces were analyzed to determine their DM, MM, EE, CP, NDF, $\mathrm{ADF}$ and $\mathrm{OM}$ content as described previously. Total carbohydrates (TC), non-fibrous carbohydrates (NFC) and NDT were estimated according to the equations described by Sniffen et al. (1992).

Milking was performed twice daily (at 6:00 a.m. and 4:00 p.m.), and the milk production per animal was recorded using meters coupled to the milking equipment. On the $15^{\text {th }}$ and $16^{\text {th }}$ days of each experimental period, milk samples were collected, in a proportional way from both milking sessions, packed in polyethylene bottles containing the preservative Bronopol $^{\circledR}$ (2-bromo-2-nitropopano-1,3-diol). And forwarded to the laboratory analysis program of the dairy herd of Paraná (PARLPR), belonging to the Paraná Association of Cattle Breeders of Dutch Breed (APCBRH), where the levels of fat, protein, lactose and solids were measured.

The milk yield, 3.5 percent fat corrected milk (kg/day), (FCM), was used the equation cited by Sklan et al. (1992). The efficiency of milk production (EMP) was computed for each cow by dividing the average production of milk by the average DM intake for each data collection period (Valadares-Filho et al. 2000). Milk samples for analysis of allantoin were deproteinized using $5 \mathrm{~mL}$ of solution to $25 \%$ trichloroacetic acid, filtered in qualitative role and stored at $-20{ }^{\circ} \mathrm{C}$.

On the $20^{\text {th }}$ day, spot urine collections were carried out approximately 4 hours after the 
TABLE II

Ingredients and chemical composition of diets containing dried waste of cassava starch extraction (WCSEd) instead of ground corn.

\begin{tabular}{|c|c|c|c|c|}
\hline \multirow{2}{*}{ Food } & \multicolumn{4}{|c|}{ Replacement levels } \\
\hline & $0 \%$ & $33 \%$ & $66 \%$ & $100 \%$ \\
\hline Corn silage $\left(\mathrm{g} \mathrm{kg}^{-1}\right)$ & 500.00 & 500.00 & 500.00 & 500.00 \\
\hline $\operatorname{WCSEd}^{1}\left(\mathrm{~g} \mathrm{~kg}^{-1}\right)$ & 0.00 & 102.36 & 192.18 & 274.86 \\
\hline Corn $\left(\mathrm{g} \mathrm{kg}^{-1}\right)$ & 323.50 & 204.33 & 97.31 & 0.00 \\
\hline Soybean meal (g/kg) & 161.88 & 177.89 & 194.54 & 208.60 \\
\hline Mineral Supplement ${ }^{2}\left(\mathrm{gkg}^{-1}\right)$ & 9.00 & 8.99 & 8.92 & 8.89 \\
\hline Dicalcium Phosphate $\left(\mathrm{gkg}^{-1}\right)$ & 5.62 & 6.43 & 7.05 & 7.65 \\
\hline \multicolumn{5}{|c|}{ Nutrients } \\
\hline Dry Matter $\left(\mathrm{g} \mathrm{kg}^{-1}\right)$ & 592.79 & 592.87 & 593.49 & 593.41 \\
\hline Organic Matter $\left(\mathrm{g} \mathrm{kg}^{-1}\right)$ & 950.78 & 950.11 & 947.00 & 946.83 \\
\hline Crude Protein $\left(\mathrm{g} \mathrm{kg}^{-1}\right)$ & 148.21 & 149.83 & 148.28 & 150.19 \\
\hline Ether Extract $\left(\mathrm{g} \mathrm{kg}^{-1}\right)$ & 15.28 & 15.03 & 14.82 & 14.62 \\
\hline Total Carbohydrates $\left(\mathrm{g} \mathrm{kg}^{-1}\right)$ & 773.87 & 773.80 & 765.94 & 773.72 \\
\hline $\mathrm{NDF}^{3}\left(\mathrm{~g} \mathrm{~kg}^{-1}\right)$ & 320.88 & 333.77 & 354.88 & 373.01 \\
\hline $\mathrm{ADF}^{4}\left(\mathrm{~g} \mathrm{~kg}^{-1}\right)$ & 180.64 & 190.74 & 204.85 & 218.93 \\
\hline $\mathrm{TDN}^{5}$ estimated $\left(\mathrm{g} \mathrm{kg}^{-1}\right)$ & 789.80 & 785.70 & 782.30 & 779.00 \\
\hline
\end{tabular}

${ }^{1}$ Dried waste of cassava starch extraction; ${ }^{2}$ Chemical composition (quantities $\mathrm{kg}^{-1}$ ): $\mathrm{Ca}-260 \mathrm{~g}, \mathrm{P}-40 \mathrm{~g}$, Co - 13 mg, Mg - 15 g, Mn - 1100 mg, Zn - 3000 mg, Se - 20 mg, I - 40 mg, S - 12 g, F - 170 mg e F - $400 \mathrm{mg}$ (commercial product); ${ }^{3} \mathrm{NDF}$ : Neutral Detergent fiber; ${ }^{4} \mathrm{ADF}$ : Acid Detergent Fiber; ${ }^{5} \mathrm{TDN}$ : Total digestible nutrients (estimated by TDN = OM (\%) /100 (26.8 + $0.595($ IVDOM (\%))) )).

morning feeding. A $10-\mathrm{mL}$ aliquot was separated and acidified with $40 \mathrm{~mL}$ of sulfuric acid $(0.036 \mathrm{~N})$ for the quantification of creatinine, allantoin and uric acid. The average daily excretion of creatinine, considered to indicate the urinary volume, was $24.05 \mathrm{mg} \mathrm{kg}^{-1} \mathrm{BW}$ (Chizzotti et al. 2007).

The excretion of total purines (PT) was estimated by the sum of the quantities of allantoin and uric acid excreted in the urine and allantoin in milk. The amount of microbial purines absorbed (PA) (mmol day $\left.{ }^{-1}\right)$ was estimated from the excretion of PT (mmol day $\left.{ }^{-1}\right)$ by means of the equation proposed by Verbic et al. (1990). The intestinal microbial nitrogen flow ( $\mathrm{g} \mathrm{MN}$ day $^{-1}$ ) was estimated from the amount of purines absorbed ( $\left.\mathrm{mmol} \mathrm{day}^{-1}\right)$, according to Chen and Gomes (1992).

To monitor metabolites, blood was collected at different times after the morning feed $(0,1,2$, 4,6 and $8 \mathrm{~h}$ ) on the $21^{\text {st }}$ day of each period, using 4-mL test tubes containing sodium fluoride, via coccygeal vein puncture. The samples were refrigerated until processing and analysis. The plasma was obtained by means of centrifugation at $3500 \mathrm{rpm}$ for $15 \mathrm{~min}$, and used for the determination of concentrations of glucose and urea, which were analyzed by means of commercial kits using the colorimetric method according to the manufacturers' instructions, with using a spectrophotometer to determination of the absorbance.

The data were subjected to analysis of variance and subsequent polynomial regression analysis, considering the levels of WCSEd $(0 ; 33 ; 66$; or $100)$ at the $5 \%$ level of probability, using a program (SAEG) developed by the Universidade Federal de Viçosa (UFV 1999).

\section{RESULTS AND DISCUSSION}

Dry matter intake was reduced as the level of substitution of corn with the starch extraction residue of cassava dried (WCSEd) increased (Table III). The reduction in intake may be associated with the 
characteristics of cassava processing, such as the rapid degradation of cassava starch (Svihus et al. 2005), which results in an increase in the amount of volatile fatty acids (VFAs) formed in the rumen which leads to the restriction of intake in response to metabolic signals of satiety (Meneghetti and Domingues 2008). These results are consistent with a study by Abrahão et al. (2006b), in which heifers fed with corn-based diets showed $10.40 \%$ intake superior to those fed with WCSEd-based diets.

\section{TABLE III}

Daily intake of dry matter and nutrients of Holstein lactating cows, receiving diets containing dried waste of cassava starch extraction (WCSEd) instead of ground corn.

\begin{tabular}{|c|c|c|c|c|c|c|}
\hline & \multicolumn{4}{|c|}{ Replacement levels } & \multicolumn{2}{|c|}{ Pvalue } \\
\hline & $0 \%$ & $33 \%$ & $66 \%$ & $100 \%$ & $\mathrm{~L}$ & Q \\
\hline BW (kg) & 644.25 & 636.75 & 635.00 & 635.75 & - & - \\
\hline $\operatorname{DMI}^{1}\left(\mathrm{~kg} \mathrm{dia}^{-1}\right)$ & 19.21 & 18.31 & 18.74 & 17.42 & 0.0254 & 0.5893 \\
\hline $\mathrm{DMI}^{2}(\% \mathrm{BW})$ & 3.01 & 2.85 & 3.03 & 2.76 & 0.0929 & 0.5893 \\
\hline $\mathrm{OMI}^{3}\left(\mathrm{~kg} \mathrm{dia}^{-1}\right)$ & 18.26 & 17.39 & 17.73 & 16.47 & 0.0198 & 0.6048 \\
\hline $\mathrm{CPI}^{4}\left(\mathrm{~kg} \mathrm{dia}^{-1}\right)$ & 2.97 & 2.94 & 3.14 & 2.82 & 0.4042 & 0.0802 \\
\hline $\operatorname{EEI}^{5}\left(\mathrm{~kg} \mathrm{dia}^{-1}\right)$ & 0.52 & 0.46 & 0.42 & 0.32 & 0.0288 & 0.3769 \\
\hline $\mathrm{TCI}^{6}\left(\mathrm{~kg} \mathrm{dia}^{-1}\right)$ & 14.77 & 13.99 & 14.17 & 13.23 & 0.0196 & 0.8132 \\
\hline $\mathrm{NDFI}^{7}\left(\mathrm{~kg} \mathrm{dia}{ }^{-1}\right)$ & 5.58 & 5.48 & 6.19 & 5.62 & 0.5899 & 0.4848 \\
\hline $\mathrm{ADFI}^{8}\left(\mathrm{~kg} \mathrm{dia}^{-1}\right)$ & 3.14 & 3.11 & 3.54 & 3.49 & 0.0076 & 0.8481 \\
\hline
\end{tabular}

${ }^{1,2}$ DMI: Dry matter intake; ${ }^{3} \mathrm{OMI}$ : Organic matter intake; ${ }^{4} \mathrm{CPI}$ : Crude protein intake; ${ }^{5} \mathrm{EEI}$ : Ether extract intake; ${ }^{6} \mathrm{TCI}$ : Total carbohydrate intake; ${ }^{7} \mathrm{NDFI}$ : Neutral detergent Fiber intake; ${ }^{8} \mathrm{ADFI}$ : Acid detergent Fiber intake.

${ }^{1} \hat{\mathrm{Y}}=19.1648-0.0149328 \mathrm{x}\left(\mathrm{R}^{2}=0.71\right) ;{ }^{3} \hat{\mathrm{Y}}=18.2166-0.0151793 \mathrm{x}\left(\mathrm{R}^{2}=0.75\right) ;{ }^{5} \hat{\mathrm{Y}}=0.503242-$ $0.000985958 \mathrm{x}\left(\mathrm{R}^{2}=0.90\right) ;{ }^{6} \hat{\mathrm{Y}}=14.7074-0.0133697 \mathrm{x} \quad\left(\mathrm{R}^{2}=0.82\right) ;{ }^{8} \hat{\mathrm{Y}}=3.09921+0.00439741 \mathrm{x}$ $\left(\mathrm{R}^{2}=0.71\right)$.

MS intake as a percentage of body weight (BW) was not influenced by the treatments, consistent with the results presented by Ramalho et al. (2006). In the latter study there was no variation in DM intake as a percentage of live weight of primiparous lactating cows fed with different diets containing cassava chips $(0,25,50,75$ and $100 \%$ replacement of maize), which have a similar composition to WCSEd. However, the intake of DM in the current study $\left(18.42 \mathrm{~kg} \mathrm{day}^{-1}\right)$ exceeded that of the former study $\left(17.40 \mathrm{~kg} \mathrm{day}^{-1}\right)$.

The intake of OM, EE and TC followed a linear pattern, decreasing with increasing substitution of corn with WCSEd, reflecting the variation observed for the intake of DM, while the ingestion of $\mathrm{CP}$ was not influenced by WCSEd.

NDF intake was not influenced by the treatments, while the ingestion of ADF showed a linear increase, probably due to the reduction in intake of DM associated with levels of NDF and ADF in the diet (Table II), as the level of WCSEd increased.

The digestibility of DM, OM, CP, EE, TC, NDF, ADF, and TDN was not influenced by the level of WCSEd (Table IV). It is likely that there was an additive effect among the ingredients in the $66 \%$ WCSEd diet, since this treatment (66\%) showed the best digestibility coefficient for all nutrients. It is possible that the synchronization between proteins and carbohydrates was better in this treatment, since there are differences in starch degradation between energy sources (Svihus et al. 2005). The rumen flora may also have improved by increasing the proportion of soybean meal in the diet (Kozloski 2011). This change in the levels of soybean meal, was needed for nutrient adequacy of diets, to maintain the diets isoproteic and isoenergetic. 
TABLE IV

Apparent digestibility of dry matter and nutrients, excreta of derivatives of purines and microbial synthesis of Holstein lactating cows, receiving diets containing dried waste of cassava starch extraction (WCSEd) instead of ground corn.

\begin{tabular}{ccccccc}
\hline & \multicolumn{3}{c}{ Replacement levels } & \multicolumn{2}{c}{ P value } \\
\cline { 2 - 7 } & $0 \%$ & $33 \%$ & $66 \%$ & $100 \%$ & $\mathrm{~L}$ & $\mathrm{Q}$ \\
\hline DMD $^{1}(\%)$ & 64.89 & 61.75 & 66.76 & 64.34 & 0.5865 & 0.8177 \\
OMD $^{2}(\%)$ & 67.58 & 62.22 & 70.00 & 67.50 & 0.4230 & 0.9275 \\
$\mathrm{CPD}^{3}(\%)$ & 64.56 & 61.63 & 68.54 & 68.25 & 0.0770 & 0.5295 \\
EED $^{4}(\%)$ & 60.54 & 61.19 & 73.48 & 71.46 & 0.1902 & 0.2382 \\
TCD $^{5}(\%)$ & 68.10 & 65.72 & 70.23 & 66.94 & 0.8578 & 0.7429 \\
NDFD $^{6}(\%)$ & 44.71 & 38.45 & 45.68 & 38.15 & 0.6870 & 0.7855 \\
ADFD $^{7}(\%)$ & 50.50 & 45.02 & 48.60 & 44.88 & 0.9005 & 0.6492 \\
TDN $^{8}(\%)$ & 66.95 & 64.72 & 68.75 & 66.66 & 0.4972 & 0.9581 \\
MAP $^{9}\left(\mathrm{mmol} \mathrm{dia}^{-1}\right)$ & 344.34 & 460.64 & 414.18 & 443.90 & 0.2210 & 0.3349 \\
$\mathrm{~N}-\mathrm{m}^{10}\left(\mathrm{~g} \mathrm{dia}^{-1}\right)$ & 250.35 & 334.90 & 301.13 & 322.73 & 0.2210 & 0.3349 \\
$\mathrm{P}-\mathrm{m} 100 \mathrm{~g}^{-1} \mathrm{OM}^{11}$ & 13.94 & 19.00 & 17.72 & 21.58 & 0.0215 & 0.1495 \\
\hline
\end{tabular}

${ }^{1} \mathrm{DMD}$ : Dry matter digestibility; ${ }^{2} \mathrm{OMD}$ : Organic matter digestibility; ${ }^{3} \mathrm{CPD}$ : Crude protein digestibility; ${ }^{4} \mathrm{EED}$ : Ether extract digestibility; ${ }^{5} \mathrm{TCD}$ : Total carbohydrate digestibility; ${ }^{6} \mathrm{NDFD}$ : Neutral detergent Fiber digestibility; ${ }^{7}$ ADFD: Acid detergent Fiber digestibility; ${ }^{8}$ TDN: Totals digestible nutrients; ${ }^{9} \mathrm{MAP}$ : Microbial Absorbed Purine; ${ }^{10} \mathrm{~N}-\mathrm{m}$ : Microbial nitrogen; ${ }^{11} \mathrm{P}-\mathrm{m} 100 \mathrm{~g}^{-1}$ OM: Microbial protein per $100 \mathrm{~g}$ of digested organic matter in the rumen.

${ }^{11} \hat{Y}=18.06133+0.0650247 x\left(R^{2}=0.77\right)$.

The digestibility of DM obtained in this study was similar to that of a study conducted with lactating cows that evaluated the inclusion in the diet of $0,8,16,24$ and $32 \%$ waste of cassava starch extraction, in which DM digestibility decreased from $68.85 \%$ to $61.08 \%$ with increased levels of inclusion (Javorski 2012). Similarly, Schmidt (2011) observed no significant variation in the digestibility of DM, obtaining an average of $64.98 \%$, when replacing corn with the silage waste of cassava starch extraction $(0,25,50,75$ and $100 \%)$.

The digestibility of OM observed in this study was similar to that observed by Schmidt (2011), who reported a digestibility of $67.32 \%$ when using silage waste of cassava starch extraction for lactating cows, while Javorski (2012) reported values between $70.45 \%$ to $63.07 \%$ when using waste of cassava starch extraction.

In contrast to the present study, Ramalho et al. (2006) observed an increase in the digestibility of EE of up to $55.86 \%$ when replacing corn with cassava chips, and attributed these changes to the variability of EE content in the samples. However, the same study reported values of TC digestibility $(69.65 \%)$ similar to those seen in the current study. Likewise, Javorski (2012) reported values between $69.19 \%$ and $60.70 \%$ with increasing levels of inclusion $(0,8,16,24$ and $32 \%)$ of waste of cassava starch extraction in the diet of lactating cows.

In terms of the digestibility of $\mathrm{CP}$, the NDF and $\mathrm{ADF}$ values were consistent with the results obtained by Schmidt (2011) $(\mathrm{DCP}=65.43 \%$; $\mathrm{DNDF}=45.18 \%$ and $\mathrm{DADF}=46.18 \%)$. The calculated percentage of TDN was not influenced by the treatments (corn and WCSEd), similar to that observed for the digestibility of nutrients.

Neither the purines absorbed nor the microbial synthesis of microbial $\mathrm{N}$ were influenced by the level of WCSEd in the diet. Only the synthesis of $\mathrm{g}$ P-microbial $100 \mathrm{~g}^{-1}$ of OM degraded in the rumen was positively affected. Differences in starch degradation may alter the efficiency of utilization of diet for microbial protein synthesis, since the replacement of corn with WCSEd reduced 
the intake of DM and OM, but did not alter the production of P-microbial; however there was an increasing linear effect for $\mathrm{g}$ P-microbial $100 \mathrm{~g}^{-1}$ of MO degraded.

The increase in the production of P-microbial $100 \mathrm{~g}^{-1}$ of MO degraded may have occurred due to a reduction in protozoa in the rumen (Kozloski 2011) caused by increased soybean meal in the diet, which resulted in an increase in EE supply (Table I and II); this increase may cause defaunation of protozoa (Martinele et al. 2008), resulting in further development of ruminal bacteria.

In this study, although the values of $\mathrm{g}$ P-microbial $100 \mathrm{~g}^{-1}$ of MO degraded in the rumen increased as WCSEd increased, they were within the range of variation described by Pathak (2008), who reported that the efficiency of microbial synthesis can range from 13 to $17.6 \mathrm{~g}$ P-microbial $100 \mathrm{~g}^{-1}$ of MO degraded in the rumen.

Milk production was negatively affected by increasing levels of substitution of corn with WCSEd, with a reduction of $0.023 \mathrm{~kg}$ of milk produced for every $1 \%$ increase in WCSEd (Table V). However, there was no effect on the constituents of milk (fat, protein, lactose, total solids and solids degreased) with the exception of the daily production $(\mathrm{kg})$ of lactose. For milk production corrected to $3.5 \%$ fat, a decreasing linear effect was observed.

TABLE V

Production and milk composition of Holstein lactating cows, receiving diets containing dried waste of cassava starch extraction (WCSEd) instead of ground corn.

\begin{tabular}{ccccccc}
\hline & \multicolumn{3}{c}{ Replacement levels } & \multicolumn{2}{c}{ P value } \\
\cline { 2 - 7 } & $0 \%$ & $33 \%$ & $66 \%$ & $100 \%$ & $\mathrm{~L}$ & $\mathrm{Q}$ \\
\hline $\mathrm{MP}^{1}\left(\mathrm{~kg} \mathrm{dia}^{-1}\right)$ & 26.17 & 25.19 & 24.59 & 23.78 & 0.0024 & 0.8016 \\
$\mathrm{CMP}\left(\mathrm{kg} \mathrm{dia}^{-1}\right)$ & 25.41 & 25.01 & 23.72 & 22.18 & 0.0335 & 0.5592 \\
$\mathrm{MPE}^{3}$ & 1.31 & 1.35 & 1.25 & 1.25 & 0.1314 & 0.7250 \\
FAT $\left(\mathrm{g} \mathrm{kg}^{-1}\right)$ & 33.33 & 34.42 & 32.77 & 30.78 & 0.3345 & 0.4744 \\
FAT $\left(\mathrm{kg} \mathrm{dia}^{-1}\right)$ & 0.87 & 0.87 & 0.81 & 0.73 & 0.0872 & 0.5044 \\
$\operatorname{PROT}^{4 \mathrm{a}}\left(\mathrm{g} \mathrm{kg}^{-1}\right)$ & 31.60 & 32.51 & 32.51 & 33.06 & 0.2961 & 0.8390 \\
$\operatorname{PROT}^{4 \mathrm{~b}}\left(\mathrm{~kg} \mathrm{dia}^{-1}\right)$ & 0.82 & 0.81 & 0.80 & 0.77 & 0.2515 & 0.6894 \\
$\mathrm{LACT}^{5 \mathrm{a}}\left(\mathrm{g} \mathrm{kg}^{-1}\right)$ & 44.33 & 42.79 & 42.99 & 43.10 & 0.2806 & 0.2552 \\
$\mathrm{LACT}^{5 \mathrm{~b}}\left(\mathrm{~kg} \mathrm{dia}^{-1}\right)$ & 1.16 & 1.07 & 1.05 & 1.02 & 0.0105 & 0.2786 \\
$\mathrm{SOLD}^{6 \mathrm{a}}\left(\mathrm{g} \mathrm{kg}^{-1}\right)$ & 84.56 & 83.67 & 83.99 & 84.60 & 0.9408 & 0.6176 \\
$\mathrm{SOLD}^{6 \mathrm{~b}}\left(\mathrm{~kg} \mathrm{dia}^{-1}\right)$ & 2.20 & 2.09 & 2.07 & 2.00 & 0.0274 & 0.7240 \\
\hline
\end{tabular}

${ }^{1}$ MP: Milk Production; ${ }^{2} \mathrm{CMP}$ : Corrected milk production to $3.5 \%$ of fat; ${ }^{3} \mathrm{MPE}$ : Milk production efficiency; ${ }^{4}$ PROT: Protein; ${ }^{5}$ LACT: Lactose; ${ }^{6} \mathrm{SOLD}$ : Degreased solids.

${ }^{1} \hat{\mathrm{Y}}=26.0930-0.023348 \mathrm{x}\left(\mathrm{R}^{2}=0.99\right) ;{ }^{2} \hat{\mathrm{Y}}=25.7186-0.032935 \mathrm{x}\left(\mathrm{R}^{2}=0.95\right) ;{ }^{5 b} \hat{\mathrm{Y}}=1.13877-$ $0.00126272 x\left(\mathrm{R}^{2}=0.89\right) ;{ }^{6 b} \hat{\mathrm{Y}}=2.18313-0.00191041 \mathrm{x}\left(\mathrm{R}^{2}=0.95\right)$.

The reduction in milk production observed in this study reflects the reduction in intake. Ramalho et al. (2006) used cassava chips, a product with a composition similar to WCSEd in terms of DM, and also observed a decreasing linear effect on milk production, and attributed this response to differences in the processes of digestion, absorption and metabolism of starch from the corn and cassava chips, and the associative effects of these foods with other dietary ingredients.
Although milk production was significantly influenced by the replacement of corn with WCSEd, the production efficiency was not altered, with an average of 1.33. Javorski (2012) no reported change in production efficiency, they obtained 1.38, higher than the value obtained in this study. Fernandes (2011) also found no variation in production efficiency when using silage waste from cassava starch extraction to feed lactating cows, but reported higher values (1.42). 
In general the constituents of milk in $\mathrm{g} \mathrm{kg}^{-1}$ do not seem to be affected by the dietary substitution, although Fernandes (2011) and Javorski (2012) showed an increasing linear response for protein, lactose and degreased solids.

The efficiency of milk production demonstrates that the reduction observed for milk production, results from the intake of DM. In this way, the use of this residue is attached to the cost benefit of its use, and supply strategies should be adopted to avoid satiety in the animals.

The inversion that has occurred in content of fat and protein, indicating the possible occurrence of subclinical acidosis. We have found no evidence of other symptoms caused by subclinical acidosis, such as diarrhea or a change in the $\mathrm{pH}$ of urine, nor was there any variation in the rumen $\mathrm{pH}$ of cannulated bovines fed the same diet (unpublished data).

The daily production of lactose and degreased solids $\left(\mathrm{kg} \mathrm{day}^{-1}\right)$ was negatively influenced by the progressive increase in the levels of WCSEd. Changes in the production of lactose might have reflected the better use of glucose supplied by corn, which is digested mostly in the small intestine, enabling an increase in energy from the viscera (Kozloski 2011). Degreased solids were influenced mainly by their components (protein, lactose and minerals), accompanying the change observed for lactose.

Plasma glucose levels were dependent on an interaction between treatments and hours after feeding (Fig. 1). Plasma glucose levels showed a quadratic effect as the corn was replaced by WCSEd (Fig. 1a), differing from the results observed by Pires et al. (2008), who found no significant changes in plasma glucose concentrations in animals fed with cassava chips as a source of starch. The glucose levels stayed within the appropriate levels for cattle, which can range from 45 to $75 \mathrm{mg} \mathrm{dL}^{-1}$ (Fernandes et al. 2012). It is possible that the change in blood glucose levels between treatments was due to differences in degradation and absorption between corn and WCSEd (Svihus et al. 2005, Ramalho et al. 2006).
To the timetables after feeding, was obtained a quadratic effect on blood glucose levels (Fig. 1b). It is likely that this change occurred as a result of the degradation processes and subsequent digestion of food, since propionate, which is produced in the rumen, contributes to the formation of up to $54 \%$ of the glucose present in the blood (Silva 1979), and the diet used, has food from high ruminal degradation. Another factor that may have influenced the variation of blood glucose was the action of insulin, the hormone that stimulates glucose uptake by tissues (Grande and Santos 2008), and when high concentrations of starch reach the intestine, it causes elevation in insulin concentration, as a metabolic response (Ramalho et al. 2006).

Plasma urea nitrogen (PUN) concentrations showed an interaction between treatments and hours after feeding, without effect among the treatments, only for the hours after feeding (Fig. 2). PUN concentrations were within the range considered adequate for lactating cows, at between 7 and $23.5 \mathrm{mg} \mathrm{dL}^{-1}$ (Lima et al. 2004).

PUN levels were reduced after feeding on the 33, 66 and 100\% WCSEd treatments. As PUN is a fast and sensitive indicator of crude protein intake, its increase may indicate an excess of protein in the diet, and its low concentration may indicate lack of protein or higher synchronism between protein and carbohydrates (Grande and Santos 2008). Another factor is intake higher amounts of EE derived from the soybean meal may cause ruminal protozoa defaunation (Martinele et al. 2008), resulting in higher consumption of ammoniacal nitrogen by bacteria, thus reducing the recycling of nitrogen in the rumen (Kozloski 2011) and consequently reducing the PUN.

\section{CONCLUSIONS}

The dried residue of cassava starch extraction can be used to feed lactating cows, with up to $100 \%$ 


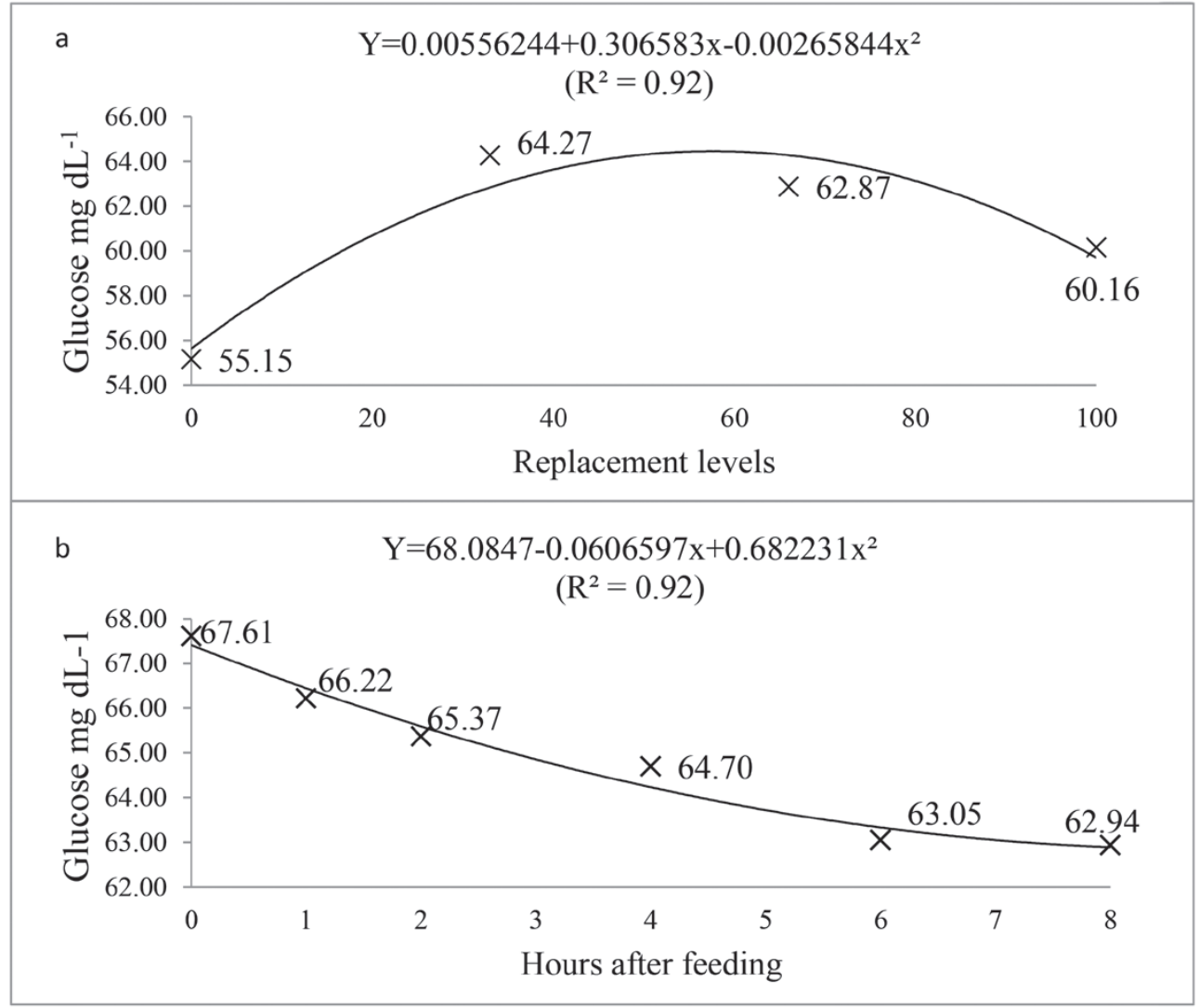

Figure 1 - Changes in plasma glucose levels depending on the use of dried waste of cassava starch extraction replacing corn in diets of lactating cows. (a) Plasma glucose concentration according to the treatments for all times; (b) Plasma glucose concentration according to the timetables for all treatments.

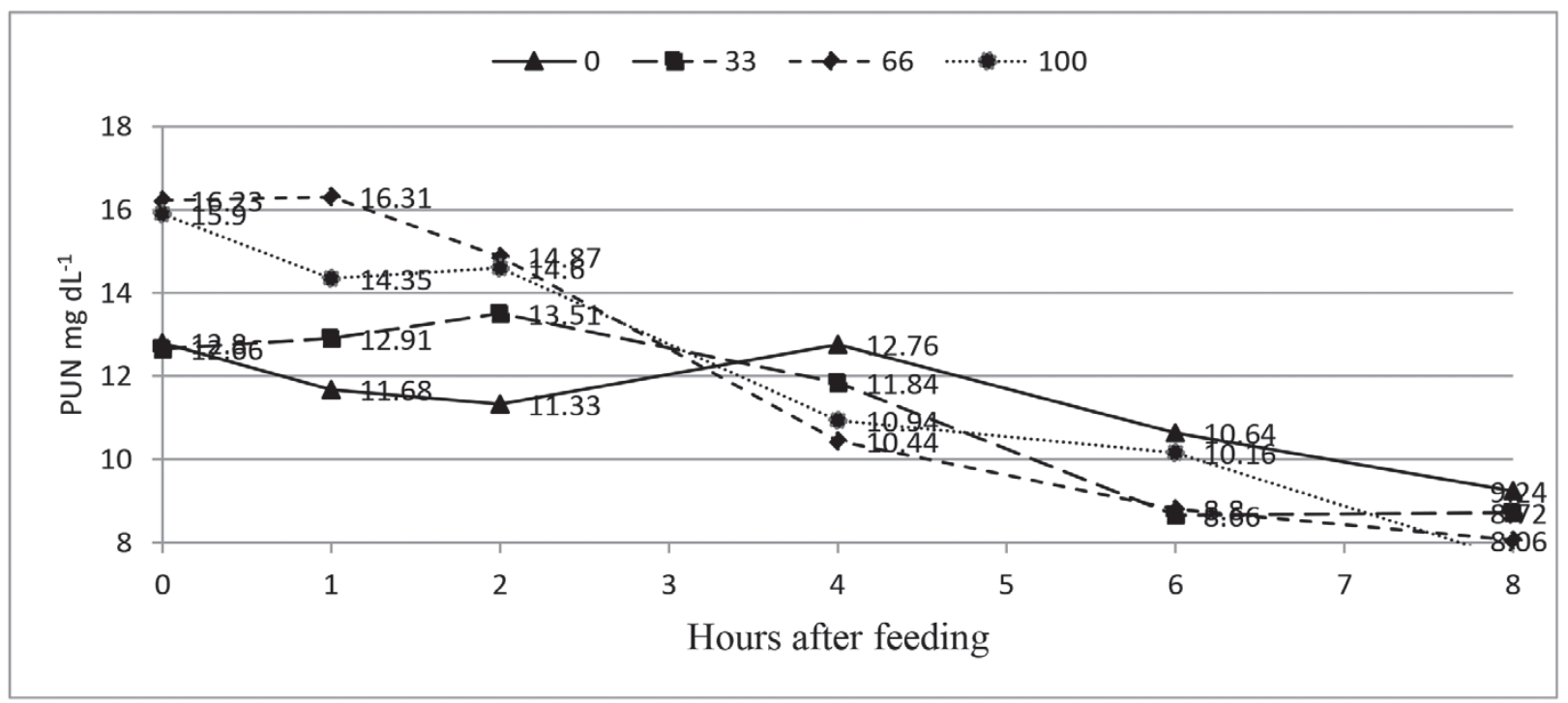

Figure 2 - Changes in plasma urea nitrogen concentration depending on the use of dried waste of cassava starch extraction replacing corn in diets of lactating cows, as a function of time after feeding.

- T33: $\hat{\mathrm{Y}}=13.5942-0.631907 x\left(\mathrm{R}^{2}=0.82\right) ;$ T66: $\hat{\mathrm{Y}}=16.6029-1.18657 \mathrm{x}\left(\mathrm{R}^{2}=0.93\right) ; \bullet \mathrm{T} 100: \hat{\mathrm{Y}}=15.8217-1.01800 \mathrm{x}\left(\mathrm{R}^{2}=0.97\right)$. 
replacement of corn. However, its use promotes a reduction in dry matter intake and therefore in the production of milk, with impacts on the profitability of the product. Feeding techniques that reduce the effect of satiety should be considered.

\section{ACKNOWLEDGMENTS}

Financial support: Conselho Nacional de Desenvolvimento Científico e Tecnológico (CNPq), Coordenação de Aperfeiçoamento de Pessoal de Nível Superior (CAPES).

\section{RESUMO}

O objetivo deste estudo foi determinar o melhor nível de aproveitamento de resíduos secos de extração de amido de mandioca (REAMs) como substituto para o milho para vacas em lactação. Quatro vacas em lactação foram alimentadas com dietas com níveis crescentes $(0,33,66$ e $100 \%)$ de REAMs como substituto para o milho. Foram avaliadas a ingestão e digestibilidade da matéria seca e de nutrientes, produção e composição do leite, parâmetros sanguíneos de glicose e uréia e síntese microbiana das dietas. Houve uma redução na ingestão de matéria seca, matéria orgânica, extrato etéreo e carboidratos totais e aumento da ingestão de fibra detergente ácido. A digestibilidade de nutrientes não foi afetada, e a síntese de proteína microbiana aumentou. Estas mudanças resultaram na redução da produção de leite, sem alterar a eficiência da produção ou os constituintes do leite, com um efeito de diminuição na produção diária de lactose, sólidos e minerais. Parâmetros metabólicos, glicose e nitrogênio ureico no plasma, mantiveram-se dentro de níveis adequados. O resíduo da extração do amido de mandioca seco pode ser usado como alimento para as vacas leiteiras para substituir o milho da ração em até $100 \%$. No entanto, seu uso promove uma redução na ingestão de matéria seca e nutrientes, bem como uma redução na produção de leite, com impactos na rentabilidade do produto.

Palavras-chave: parâmetros sanguíneos, digestibilidade, ingestão, síntese microbiana, produção.

\section{REFERENCES}

Abrahão JJS, Prado IN, Marques JÁ, Perotto D AND LUGAO SMB. 2006b. Avaliação da substituição do milho pelo resíduo seco da extração da fécula de mandioca sobre o desempenho de novilhas mestiças em confinamento. Rev Bras Zootec 35: 512-518.

Abrahão JJS, Prado IN, Perotto D, Zeoula LM, LANCANOVA JAC AND LUGaO SMB. 2006a. Digestibilidade de dietas contendo resíduo úmido de mandioca em substituição ao milho para tourinhos em terminação. Rev Bras Zootec 35: 512-518.

AOAC - ASSOCIATION OF OfFICIAL ANALYTICAL CHEMISTS. 1990. Official methods of analysis. $16^{\text {th }}$ ed., Arlington: AOAC International, $1025 \mathrm{p}$.

CHEN XB AND GOMES MJ. 1992. Estimation of microbial protein supply to sheep and cattle based on urinary excretion of purine derivatives - an overview of technical details. Bucksburnd: Rowett Research Institute/ International Feed Research Unit, $21 \mathrm{p}$.

Chizzotti ML, Valadares-Filho SC, Valadares RFD, Chizzoti FHM, MARCONDES MI AND FonseCA MA. 2007. Consumo, digestibilidade e excreção de uréia e derivados de purinas em vacas de diferentes níveis de produção de leite. Rev Bras Zootec 36: 138-146.

FELIPE FI, Alves LRA AND VIEIRA RM. 2013. Fécula de mandioca, produção na Tailândia versus Brasil. Mercado \& Negócios, Agroanalysis.

FERnANDES SR, Freitas JÁ, SOUZA DF, Kowalski LH, DitTrich AL, Rossi JunIOR P AND SILVA CJA. 2012. Lipidograma como ferramenta na avaliação do metabolismo energético em ruminantes. Bras Agrociência 18: 21-32.

FERNANDES T. 2011. Silagem de resíduo úmido de fécula de mandioca na alimentação de vacas em lactação: produção e composição do leite. Universidade Estadual do Oeste do Paraná, Centro de Ciências Agrárias, 25 p.

GRANDE PA AND SANTOS GT. 2008. O uso do perfil metabólico na nutrição de vacas leiteiras. Núcleo Pluridisciplinar de Pesquisa e Estudo. Available at: http://people.ufpr. br/ freitasjaf/artigos/perfilmetabolicovacas.pdf Last accessed: 20-01-2014.

JAVORSKI CR. 2012. Utilização de resíduo úmido de fécula de mandioca na dieta de vacas holandesas em lactação. Universidade Estadual do Oeste do Paraná, Centro de Ciências Agrárias, $55 \mathrm{p}$.

Jobim CC, Nussio LG, ReIS RA AND SCHMidt P. 2007. Avanços metodológicos na avaliação da qualidade da forragem conservada. Rev Bras Zootec 36: 101-119.

Kozloski GV. 2011. Bioquímica dos Ruminantes. Santa Maria, $216 \mathrm{p}$.

KUNKLE WE AND BATES DB. 1998. Evaluating feed purchasing options: energy, protein, and mineral supplements. Gainesville: University of Florida, p. 59-70.

Lima MLP, Berchielli TT, LEME PR, NOGUEIRA JR AND PINHEIRO MG. 2004. Concentração de nitrogênio uréico plasmático (nup) e produção de leite de vacas mestiças mantidas em gramíneas tropicais sob pastejo rotacionado. Rev Bras Zootec 33: 1616-1626. 
LIPPKE H, ELLIS WC AND JACOBS F. 1986. Recovery of indigestible fiber from feces of sheep and cattle on forage diets. J Dairy Sci 69: 403-412.

MARTINELE I, EIFERT EDC, LANA RDP, ARCURI PB AND DAgosto M. 2008. Efeito da monensina e do óleo de soja sobre os protozoários ciliados do rúmen e correlação dos protozoários com parâmetros da fermentação ruminal e digestivos. Rev Bras Zootec 37: 1129-1136.

MeneghetTi CDC AND Domingues JL. 2008. Características nutricionais e uso de subprodutos da agroindústria na alimentação de bovinos. Rev E. Nutritime 5: 512-536.

NRC - NATional Research Council. 2001. Nutrient Requirements of Dairy Cattle. Washington, D.C., 381 p.

PATHAK AK. 2008. Various factors affecting microbial protein synthesis in the rumen. Veterinary World 1: 186-189.

Pires AV, Susin I, SANTOS FAP, MENDES CQ, OliveiraJUNIOR RC FERNANDES JJR AND SIMAS JMC. 2008. Efeito de fontes e formas de processamento do amido sobre o desempenho e o metabolismo do nitrogênio em vacas Holandesas em lactação. Rev Bras Zootec 37: 1456-1462.

RAMALHO RP, FERREIRA MA, VÉRAS ASC, LIMA LE AND ROCHA VRRA. 2006. Substituição do milho pela raspa de mandioca em dietas para vacas primíparas em lactação. Rev Bras Zootec 35: 1221-1227.

REgINATTO V, LAMAISON FC, AMANTE ER AND ANTONIO RV. 2011. Long-term effect of nutrient supplementation of cassava wastewater on biohydrogen production by mixed culture. Ind Biotechnol 7: 143-150.

SCHMIDT EL. 2011. Silagem de resíduo úmido de fécula de mandioca em substituição ao milho da ração para vacas em lactação: consumo e digestibilidade da matéria seca e dos nutrientes. Universidade Estadual do Oeste do Paraná, Centro de Ciências Agrárias, 26 p.

SILVA JFC. 1979. Fundamentos de Nutrição de Ruminantes. Piracicaba, ed., Livrocerres, p. 384.
SKLAN D, AShKENAZI R, BRAUn A, DEVORIN A AND TABORI K. 1992. Fatty acids, calcium soaps of fatty acids, and cottonseeds fed to high yielding cows. J Dairy Sci 75: 2463-2472.

SNIFFEN CJ, O'CONNOR JD, VAN-SOEST PJ, FOX DG AND RUSSELL JB. 1992. A net carbohydrate and protein system for evaluating cattle diets: II. Carbohydrate and protein availability. J Ani Sci 70: 3562-3577.

SviHUS B, UHLEN AK AND HARSTAD OM. 2005. Effect of starch granule structure, associated components and processing on nutritive value of cereal starch: A review. Ani Feed Sci Technol 122: 303-320.

TILley JMA AND TERRY RA. 1963. A two stage technique for the in vitro digestion of forage crops. J British Grass 18: 104-111.

VALADARES-FilHo SC, BRoDERICK GA, VALADARES RFD AND CLAYTON MK. 2000. Effect of replacing alfalfa silage with high moisture corn on nutrient utilization and milk production. J Dairy Sci 83: 106-114.

VAN-SOEST PJ, ROBERTSON JB AND LEWIS BA. 1991. Carbohydrate methodology, metabolism, nutritional implications in dairy cattle. J Dairy Sci 74: 3583-3597.

Verbic J, Chen XB, MACleOd NA AND ORSKOV ER. 1990. Excretion of purine derivatives by ruminants. Effect of microbial nucleic acid infusion on purine derivative excretion by steers. J Agric Sci 114: 243-248.

UFV - UniVERsidAde Federal de ViçosA. 1999. Sistema de análises estatísticas e genéticas - SAEG. Versão 8.Viçosa, MG, 142 p.

WALler JN, Merchen N, Hanson T AND Klopfenstein T. 1980. Effect of sampling intervals and digesta markers on abomasal flow determinations. J Ani Sci 50: 1122. 
